\title{
Hyaluronate in rheumatology and orthopaedics: Is there a role?
}

\author{
Robin K Strachan. Paul Smith, Dugald L Gardner
}

The clinical use of connective tissue substitutes is controversial. This viewpoint aims at outlining and highlighting some of the notable work in the field and at encouraging debate.

Hyaluronate is a glycosaminoglycan with a repeating disaccharide structure that is composed of D-glucuronic acid in linkage to $N$-acetyl-Dglucosamine. Free hyaluronic acid only occurs under laboratory conditions and therefore hyaluronate or hyaluronan are the recommended terms.

Hyaluronate is present in synovial fluid as the major macromolecular component and is responsible for the intrinsic viscoelasticity so characteristic of this fluid. ${ }^{1}$ This viscoelasticity is a function of both the concentration and molecular weight of the hyaluronate within synovial fluid. ${ }^{2-5}$ Molecules of $1 \times 10^{6}$ molecular weight are formed from 2500 disaccharides and have an extended length of around $2.5 \mu \mathrm{m}$. In solution the chain behaves as an expanded random coil with a diameter of $500 \mathrm{~nm}$, with the domain including a large amount of solvent. How the molecules actually behave and interact under physiological conditions in synovial fluid is unclear. They show, however, so-called thixotropic qualities where viscosity or shear resistance falls as shear rate increases.

It has been suggested that the decrease in concentration of hyaluronate is a more important factor in the arthropathies than the observed reduction in molecular weight. ${ }^{5}$ High molecular weight hyaluronate in synovial fluid has been shown to be an inhibitor of cellular proliferation. ${ }^{6}$ Concentrations of hyaluronate in normal joints range from 1.45 to $2.94 \mathrm{mg} / \mathrm{ml}$ in comparison with the protein fraction of $10 \cdot 4$ to $15 \cdot 8$ $\mathrm{mg} / \mathrm{ml}^{2}$

Hyaluronate filaments are bound to proteoglycan molecules and link proteins to form macromolecular aggregates in cartilage. ${ }^{7-9}$ In weightbearing areas twice as much hyaluronate can be found in the superficial layers of cartilage. ${ }^{10}$ Only the $200 \mathrm{~nm}$ thick layer, the deeper of two surface layers overlying cartilage zone I, seems to contain hyaluronate. A $50 \mathrm{~nm}$ superficial layer on the cartilage surface in close association with the hyaluronate layer seems to be composed of an indeterminate protein complex, which probably includes fibronectin. ${ }^{11}$

With age there is a fivefold increase in hyaluronate concentration in the joint articular cartilage, but this is of decreasing molecular weight. ${ }^{9}$ Newly synthesised hyaluronate shows little molecular weight change with age, sug- gesting that some form of extracellular modification or breakdown process is occurring. This leads to a reduction in size of the macromolecular aggregates within the collagen mesh.

A study in which radiolabelled hyaluronate was injected into joints found incorporation of hyaluronate into synovium by two hours and into cartilage by six hours. ${ }^{12}$ Menisci did not readily become labelled. Diffusion into cartilage indicated that prior degradation was occurring. Persistence of radioactivity suggested the possibility of resynthesis of degraded hyaluronate by chondrocyte activity. Some of the persistent radioactivity might perhaps be due to reuse of sugars for the synthesis of molecules other than hyaluronate. The autoradiographic patterns, however, were similar to those of other studies showing the incorporation of proline or sulphate into proteoglycans adjacent to chondrocytes.

\section{Cellular effects of hyaluronate}

The effect of hyaluronate upon cellular function depends upon concentration, molecular weight, and the cell type in question. Hyaluronate bonded to cell-cell culture substrate inhibits differentiation of myoblasts ${ }^{13} 14$ but stimulates the differentiation of chondroblasts. ${ }^{15}$ This chondroblast differentiation is dependent on molecular size, being activated in the molecular weight range $2-4 \times 10^{5}$, with no effect at a molecular weight greater than $10^{6} \mathrm{kD} .^{16}$ The extracellular concentration of hyaluronate regulates the synthesis of proteoglycans during cartilage maturation and in repair processes. ${ }^{9} 17$

Hyaluronate inhibits the migration of vascular endothelial cells but promotes the migration of other cell types. ${ }^{18-22}$ Oligosaccharides of hyaluronate are angiogenic, however. ${ }^{23}$

Migration of mesenchymal cells in vivo is favoured by matrices abundant in hyaluronate. ${ }^{24} 25$ Leucocyte movement, adherence, and phagocytosis are all inhibited at high concentrations of hyaluronate, ${ }^{26-30}$ with low concentrations producing stimulation of cell activity, both in vitro and in vivo. ${ }^{31} 32$ High concentrations of hyaluronate can inhibit and low concentrations mediate aggregation in various cell types. ${ }^{29}$ 33-39 Aggregation of virally transformed cells is achieved only at a low concentration of hyaluronate. With high concentrations all of the hyaluronate receptors are assumed to be occupied, leaving no sites available for cross linking of adjacent cells. Cell repulsion due to the charged bulk of hyaluronate might be occurring. ${ }^{40} 41$ 
Recent work has provided evidence that hyaluronate acting within the joint can produce analgesia. ${ }^{42}$ Hyaluronidase enhanced sensitivity but hyaluronate reduced pain in the presence of nociceptive agents. Hyaluronate oligosaccharides failed to show any analgesic activity in this model.

\section{Hyaluronate and rheumatoid arthritis}

During inflammation, such as in the rheumatoid joint, there is a decrease in production, polymerisation, molecular size, and concentration of hyaluronate. $^{2-6}$ The observed depolymerisation of hyaluronate may be mediated by oxygen derived free radicals, generated by inflammatory cells. ${ }^{43}$ Also, lining cells isolated from the rheumatoid joint produce hyaluronate with an unexpectedly low molecular weight. ${ }^{44} 45$ Normal synovial fluid concentrations of hyaluronate seem to have a series of effects upon the inflammatory response. ${ }^{26-33}$ Possibly, removal of the inhibitory effects of 'normal' hyaluronate results in synovial cell hypertrophy, and hyaluronate oligosaccharides may be angiogenic. ${ }^{23}$ Increase of circulating hyaluronate has been found to be significantly higher in rheumatoid patients after physical activity. ${ }^{46}$ Decreased synovial fluid viscosity might possibly accelerate secondary osteoarthrosis.

\section{Hyaluronate and osteoarthrosis}

Idiopathic osteoarthrosis is characterised by collagen fibre disorganisation, degradation of proteoglycans, and erosion. Physical breakdown of hyaluronate and proteoglycans has been found under conditions of high shear, but these conditions are unlikely to occur regularly within cartilage. ${ }^{47}$ The strength and stiffness of cartilage, osmotic pressure, and the aggregating capacity of the proteoglycans do not show the same degree of reduction with age as the large reduction in aggregate size. ${ }^{48} 49$ Also with age, protein, keratan sulphate, and hyaluronate concentrations are all increased as aggregate size falls, but dissociated proteoglycans form aggregates in direct proportion to hyaluronate concentration. ${ }^{49}$

It is still thought that aggregate size must be a factor maintaining these molecules within cartilage, however. 9 The viscosity of aggregates in solution, dependent on shear rate, varies with concentration, but this is not believed to be a contributing factor in aggregate destruction within cartilage. ${ }^{50}$

Factors playing a part in cartilage degeneration are thought to be chondrocyte proteinase activity and free radical attack, explaining the accumulation of breakdown products related to age. This process might be accelerated during inflammatory episodes. ${ }^{51}$ For technical reasons it has been difficult to determine experimentally the possible participation of hyaluronidase in the development of osteoarthritis. ${ }^{9}$

\section{Systemic events}

Studies have found a correlation between serum concentrations of keratan sulphate and hyalu- ronate and disease severity in osteoarthritis. ${ }^{52} 53$ Other workers have shown partial protective effects of systemic administration of glycosaminoglycans after meniscectomy in a canine model of osteoarthritis. ${ }^{54}$

Radiolabelled material in the bloodstream after intra-articular injection of hyaluronate suggests that further study of systemic events might assist our understanding of joint physiology. ${ }^{12}$ Apparently, hyaluronate is synthesised in synovium, partly broken down within the joint, and then travels by the lymphatic system to be taken up mainly by lymph nodes where it is degraded. Alternatively, it may continue into the bloodstream to be degraded in the liver, kidney, and spleen. Turnover in the bloodstream is normally in the range of 0.3 to 1.0 $\mathrm{g} / \mathrm{min} / \mathrm{kg}$ body weight, and the half life of free unbound hyaluronate is two days. ${ }^{55}$ On the other hand, as has been previously stated, some molecules within a joint become incorporated into cartilage aggregates.

\section{Therapeutic effects?}

Is commercially produced hyaluronate an attractive treatment option in osteoarthritis? The serendipitous finding that intra-articular administration of hyaluronate in race horses negated the functional effects of post-traumatic arthritis was an early 'clinical' observation. ${ }^{56}$ Cruciate ligament section in dogs induced synovial proliferation and increased production of hyaluronate. ${ }^{57} \mathrm{~A}$ recent study using the Pond-Nuki experimental model of osteoarthritis in dogs attempted to measure the biochemical and morphological benefits of administration of hyaluronate. ${ }^{58} 59$ Treated joints showed significant reductions in soluble glycosaminoglycans released as a result of the induced joint instability. Cessation of the weekly injections caused a gradual regression in benefit. Inhibition of the development of a 'fibroblast-like' layer was found in the treated group and 'lameness' was reduced.

\section{Human clinical therapeutic studies}

A number of studies have now reported clinical improvement after hyaluronate treatment in humans. ${ }^{60-66}$ Variable degrees of pain relief and improved joint function have been recorded. Often, no significant effects were seen in patients with gross morphological changes, but less severe cases showed improvement and the onset of clinical benefit was 'rapid' ${ }^{40}$ Other investigators have described longlasting benefit, however, even after withdrawal of treatment. ${ }^{64-66}$

One recent trial of the intra-articular injection of hyaluronate in osteoarthritis of the knee found significant reduction in pain on movement and at rest, but no marked differences in the activities of daily living. ${ }^{67}$ The regimen consisted of up to 11 injections in 23 weeks. A noteworthy feature of every study was the lack of serious side effects produced by hundreds of injections. The use of hyaluronate was proposed where other drugs were contraindicated. 


\section{Orthopaedic indications?}

Excessive use of saline rather than lactate solutions during lengthy arthroscopic procedures can have a deleterious effect upon chondrocyte metabolism. ${ }^{68}$ Work still has to be carried out to establish whether other constituents, such as hyaluronate, ought to be incorporated. The anti-inflammatory, analgesic and lubricating properties of hyaluronate suggest the use of hyaluronate as a postoperative instillation. ${ }^{7} 8$ 26-3342 60-66 69 Other constituents may also be required. They might include the normal giycoprotein fraction, which is apparently necessary to maintain boundary type lubrication at the cartilage surface. This fraction is itself an excellent lubricant. ${ }^{70}$

Reports have described decreases in granulation tissue reaction and scarring, fewer adhesions, and improved tendon healing after the installation of hyaluronate. ${ }^{71-74}$ The results seem to be an improvement over other materials that act as barriers to fibrinogen and blood cells. ${ }^{75}$ Unlike clinical practice, however, some of the experimental models used immobilised tendons after repair. ${ }^{76} 77$

A recent inquiry reported that a single injection of hyaluronate improved the healing frequency of a partial laceration in the anterior cruciate ligament in the rabbit, ${ }^{78}$ and a recent abstract has confirmed reduction of dural adhesions in a rabbit model after laminectomy. ${ }^{79}$

The possibilities of using hyaluronate after total joint replacement, nerve repair, tissue resection, trauma, and cartilage repair are subjects for future study.

\section{Conclusions}

A recent symposium article described the clinical uses of crosslinked forms of hyaluronate which have been given the generic name of Hylans. ${ }^{80}$ The procedures described include socalled 'space-making viscosurgical tools', 'viscosurgical implants', 'arthroscopic viscosurgery', 'matrix engineering', 'promotion of tissue regeneration', and 'tissue augmentation'. The nature of these effects has been discussed in this article. There is now enough evidence to stimulate interest in large scale, controlled clinical investigations into the effects of the administration of hyaluronate and other connective tissue substitutes. These trials might also permit evaluation of different regimens, molecular weights, and concentrations of such substitutes.

The continued support of the Arthritis and Rheumatism Council for Research is gratefully acknowledged.

1 Hutadolik N, Gosh P, Brooks P M. Binding of haptoglobin, inter-alpha-trypsin inhibitor and alpha-1 proteinase inhibitor to synovial fluid hyaluronate and the influence of these proteins on its degradation by oxygen derived free radicals. Ann Rheum Dis 1988; 47: 377-85.

2 Balazs E A, Watson D, Duff I F, Roseman S. Hyaluronic acid in synovial fluid. 1. Molecular parameters of hyaluronic acid in normal and arthritic human fields. Arthritis Rheum 1967; 10: 357-75.

3 Balazs E A. The physical properties of synovial fluid and the special role of hyaluronic acid. In: Helfet A, ed. Disorders of the knee. Philadelphia: Lippincott, 1974: 61-74.

4 Hamerman D, Shuster $H$. Synovial fluid hyaluronate in rheumatoid arthritis. Arthritis Rheum 1958; 1: 523-31.
5 Dahl L B, Dahl I M, Engstrom-Laurent A, Granath $K$ Concentration and molecular weight of sodium hyaluronate in synovial fluid from patients with rheumatoid arthriti and other arthropathies. Ann Rheum Dis 1985; 44: 817-22.

6 Goldberg R L, Toole B P. Hyaluronate inhibition of cell proliferation. Arthritis Rheum 1987; 30: 769-78.

7 Nerot S, Heinegard D, Audell L, Olsson S E. Articular cartilage proteoglycans in ageing and ostearthritis. Biochem 1978; 169: 143-56.

8 Balazs E A, Bloom G D, Swann D A. Fine structure and glycosaminoglycan content of the surface layer of articular cartilage. Fed Proc 1966; 25: 1813.

9 Holmes $M \mathbb{W}$ A, Bayliss $M$ T, Muir H. Hyaluronic acid in human articular cartilage. Age related changes in conten and size. Biochem f 1988; 250: 435-41.

10 Manicourt D H, Pita J C. Quantification and characterisation of hyaluronic acid in different topographical areas of normal articular cartilage from dogs. Coll Relat Res 1988 1: $39-47$.

11 Orford C R, Gardner D L. Ultrastructural histochemistry of the surface lamina of normal articular cartilage. Histochem $\mathcal{f}$ 1985; 17: 223-33.

12 Antonas K N, Fraser J R E, Muirden K D. Distribution of biologically labelled radioactive hyaluronic acid injected into joints. Ann Rheum Dis 1973; 32: 103-11.

13 Kujawa M J, Tepperman K. Culturing chick muscle cells on glycosaminoglycan substrates: Attachment and differentiaglycosaminoglycan substrates: Attact
tion. Dev Biol 1983; 99: 277-86.

14 Kujawa M J, Pechak D J, Fizman M Y, Caplan A I. Hyaluronic acid bonded to cell culture surfaces inhibits the process of myogenesis. Dev Biol 1986; 113: 10-16.

15 Kujawa M J, Caplan A I. Hyaluronic acid bonded to cell culture surfaces stimulates chondrogenesis in stage $24 \mathrm{limb}$ mesenchyme cell cultures. Dev Biol 1986; 114: 504-18.

16 Kujawa M J, Carrino D A, Caplan A I. Substrate bonded hyaluronic acid exhibits a size dependent stimulation of chondrogenic differentiation of stage 24 limb mesenchymal chondrogenic differentiation of stage 24 limb

17 Bansal M K, Ward H, Mason R M. Proteoglycan synthesis in suspension culture of swarm rat chondrosarcoma chondrosuspension culture of swarm rat chondrosarcoma chondrocytes and inhibition by exogenou
Biochem Biophys 1986; 246: 602-10.

18 Feinberg $R$ N, Beebe D C. Hyaluronate in vasculogenesis. Science 1983; 220: 1177-9.

19 Bernanke D H, Markwald R R. Effects of hyaluronic acid on cardiac cushion tissue cells in collagen matrix cultures. Texas Reports on Biology and Medicine 1979; 32: 271-85.

20 Abatangelo G, Martinelli M, Vecchia P. Healing of hyaluronate enriched wounds: histological observations. $\mathcal{f}$ Surg Res 1983; 35: 410-6.

21 Turley E A, Bowman P, Kytryk M A. Effects of hyaluronic acid and hyaluronate-binding proteins on cell motility and contact behaviour. F Cell Sci 1985; 78: 133-45.

22 Doillon C J, Silver F H. Collagen based wound dressing effects of hyaluronic acid and fibronectin on wound effects of hyaluronic acid and

23 West D C, Hampson I N, Arnold F, Kumar S. Angiogenesis induced by degradation products of hyaluronic acid. Science 1985; 228: $1324-6$.

24 Toole B P. Glycosaminoglycans in morphogenesis. In: Hay E D, ed. Cell biology of the extracellular matrix. New York: Plenum Press, 1981: 259-95.

25 Toole B P, Goldberg R L, Chi-Rosso G, Underhill C D Orkin R W. Hyaluronic-cell interactions. In: Trestad R L, ed. The role of the extracellular matrix in development. New York: Alan R Liss, 1984: 43-66.

26 Brandt K. Modification of chemotaxis by synovial fluid hyaluronate [Abstract]. Arthritis Rheum 1970; 13: 308-9.

27 Brandt $K$. The effect of synovial hyaluronate on the ingestion of monosodium urate crystals by leucocytes. Clin Chim of monosodium urate

28 Forrester J V, Balazs E A. Inhibition of phagocytosis by high molecular weight hyaluronate. Immunology 1980; 40: 435-46.

29 Forrester J V, Lackie J M. Effect of hyaluronic acid on neutrophil adhesion. $\mathcal{F}$ Cell Sci 1981; 50: 329-44

30 Forrester J V, Wilkinson P C. Inhibition of leucocyte locomotion by hyaluronic acid. $\mathrm{F}$ Cell Sci $1981 ;$ 48: 315-31.

31 Hakansson L, Venge P. The combined action of hyaluronic acid and fibronectin stimulates neutrophil migration. f Immunol 1985; 135: 2735-9.

32 Hakansson L, Hallgren R, Venge P. Regulation of granulocyte function by hyaluronic acid. In vitro and in vivo effects on phagocytosis, locomotion and metabolism. $\mathcal{F}$ Clin Invest on phagocytosis, locon

33 Fraser J R E, Clarris B J. On the reactions of human synovial cells exposed to homologous leukocytes in vitro. Clin Exp Immunol 1970; 6: 211-25.

34 Pessac B, Defendi V. Cell aggregation: role of acid mucopolysaccharides. Science 1972; 175: 898-900.

35 Wasteson A, Estermark B, Lindahl U, Ponten J. Aggregation of feline lymphoma cells by hyaluronic acid. Int $\mathcal{f}$ Cancer 1973; 12: 169-78.

36 Underhill C B, Dorfman A. The role of hyaluronic acid in intercellular adhesion of cultured mouse cells. Exp Cell Res 1979; 117: 155-64.

37 McBride W H, Bard J B. Hyaluronidase sensitive halos around adherent cells: their role in blocking lymphocytemediated cytolysis. F Exp Med 1979; 149: 507-15.

38 Love S H, Shannon B T, Myrvik Q N, Lynn W S. Characterisation of macrophage agglutinating factor as a hyaluronic acid-protein complex. Fournal of the Reticulo endothelial Society 1979; 25: 269-82.

39 Wright T C, Underhill C B, Toole B P, Karnovsky M J. Divalent cation-independent of rat-I fibroblasts infected 
with a temperature sensitive mutant of Rous sarcoma virus. Cancer Res 1981; 41: 5107-13.

40 Underhill C B, Toole B P. Receptors for hyaluronate on the surface of parent and virus transformed cell lines: binding surface of parent and virus transformed cell lines: binding

41 Underhill C B. Interaction of hyaluronate with the surface of simian virus 40-transformed $3 \mathrm{t} 3$ cells: aggregation and simian virus 40-transformed $3 \mathrm{t} 3$ cells: agg
binding studies. $\mathcal{f}$ Cell $S_{c i} 1982 ; 56$ : 177-89.

42 Gotoh S, Miyazaki K, Onaya J, Sakamoto T, Tokuyasu K, Namiki $O$. Experimental knee pain model in rats and the effect of sodium hyaluronate. Folia Pharmacologica faponica 1988; 92: 17-27.

43 Greenwald R A, Moak S A. Degradation of hyaluronic acid by polymorphonuclear leucocytes. Inflammation 1986; 10: 15-30.

44 Dahl I M S, Husby G. Hyaluronic acid production in vitro by synovial lining cells from normal and rheumatoid joints. Ann Rheum Dis 1985; 44: 647-57.

45 Vuorio E, Einola S, Hakkarainen S, Penttinen S. Synthesis of underpolymerised hyaluronic acid by fibroblasts cultured underpolymerised hyaluronic acid by fibroblasts cultured Int $1982 ; 2: 97-102$.

46 Engstrom-Laurent A, Hallgren R. Circulating hyaluronic acid levels vary with physical activity in healthy subjects and in rheumatoid arthritis patients: relationship to synovitis mass and morning stiffness. Arthritis Rheum 1987; 30: 1333-8.

47 Hascall V C, Sadjera S W. Proteinpolysaccharide complex from bovine nasal cartilage: The function of glycoprotein in the formation of aggregates. I Biol Chem 1969; 244: 2384-96.

48 Urban J P G, Maroudas A, Bayliss M T, Dillon J. Swelling pressures of proteoglycan at the concentrations found pressures of proteoglycan at the concentrations fo
in cartilagenous tissues. Biorheology 1979; 16: 447-64.

49 Bayliss $M$ T, Ali S Y. Age related changes in the composition and structure of human articular-cartilage proteoglycans. and structure of human articula

50 Hardingham T E, Muir H, Kwan M K, Lai W M, Mow V C. Viscoelastic properties of proteoglycan solutions with varying proportions present as aggregates. $\mathcal{F}$ Orthop Res 1987; 5: $36-46$

51 Roughley P J, Roberts C R, Mort J S. The degradation of human articular cartilage proteoglycan aggregate by free radicals [Abstract]. Transactions of the American Orthopedic Research Society 33rd Annual Meeting 1987; 12: 250.

52 Leipold H R, Goldberg R L, Lust G. Canine serum keratan sulphate and hyaluronate concentrations. Arthritis Rheum 1989; 32: 312-21.

53 Biork J, Kleinau S, Tengblad A, Smedegard G. Elevated levels of serum hyaluronate and correlation with disease levels of serum hyaluronate and correlation with disease 1989; 32: 306-11.

54 Hannan N, Ghosh P, Bellenger C, Taylor T. Systemic administration of glycosaminoglycan polysulphate (Arteparon) provides partial protection of articular cartilage from damage produced by meniscectomy in the canine. 7 Orthop Res 1987; 5: 47-59.

55 Fraser J R E, Laurent T C. Turnover and metabolism of hyaluronan. The biology of hyaluronan. Chichester: Wiley, 1989: 41-53. (Ciba Foundation Symposium, No 143.)

56 Butler J, Rydell N W, Balazs E A. Hyaluronic acid in synovial fluid. VI. Effect of intra-articular injection of hyaluronic acid on the clinical symptoms of arthritis in track horses. Acta Vet Scand 1970; 11: 139-55.

57 Myers S L, Brandt K D. Studies of synovial hyaluronic acid synthesis in canine osteoarthritis. $\mathcal{F}$ Rheumatol 1987; 14: $1150-5$.

58 Abatangelo G, Botti $P$, Del Bue $M$, et al. Intra-articular injections in the Pond-Nuki experimental model of osteoarthritis in dogs. I. Biochemical results. Clin Orthop 1989; 241: 278-85.

59 Schiavinato A, Lini E, Guidolin D, et al. Intra-articular injections in the Pond-Nuki experimental model of osteoarthritis in dogs. II. Morphological findings. Clin Orthop 1989; 241: 286-99.

60 Peyron J G, Balazs E A. Preliminary clinical assessment of sodium hyaluronate injection into human arthritic joints. Pathol Biol (Paris) 1974; 22: 731-6.
61 Weiss C, Balazs E A, St Onge R, Denglinger J L. Clinical studies of the intra-articular injection of Healon in the treatment of osteoarthritis of human knees. Semin Arthritis Rhewen 1980; 11 (suppl 1): 143-4.

62 Namiki $O$, Toyoshima H, Morisaki N. Therapeutic effect of intra-articular injection of high molecular weight hyaluronic acid on osteoarthritis of the knee. Int $\mathcal{J}$ Clin Pharmacol Ther Toxicol 1982; 20: 501-7.

63 Kopp S, Wenneberg B, Haraldson T, Carlsson G E. The short-term effect of intra-articular injections of sodium hyaluronate and corticosteroid on temperomandibular joint pain and dysfunction. F Oral Maxillofac Surg 1985; 43: 429-35.

64 Kopp S, Carlsson G E, Haraldson T, Wenneberg B. Longterm effect of intra-articular injections of sodium hyaluronate and corticosteroid on temperomandibular joint arthritis. F Oral Maxillofac Surg 1987; 45: 929-35.

65 Punzi L, Schiavon F, Ramonda R, Malatesta V, Gambari P, Todesco S. Intra-articular hyaluronic acid in the treatment Todesco $S$. Intra-articular hyaluronic acid in the treatment of inflammatory and non-inflammatory knee

66 Grecomoro G, Martorana U, Di Marco C. Intra-articular treatment with sodium hyaluronate in gonarthritis: a controlled clinical trial versus placebo. Pharmatherapeutica 1987; 5: 137-41.

67 Dixon A St J, Jacoby R K, Berry H, Hamilton E B D. Clinical trial of intra-articular injection of sodium hyaluronate in patients with osteoarthritis of the knee. Curr Med Res Opin 1988; 11: 205-13.

68 Reagan B F, McInerny V K, Treadwell B V, Zarins B, Mankin $\mathrm{H}$ J. Irrigating solutions for arthroscopy. $\mathcal{F}$ Bone foint Surg [Am] 1983; 65: 629-31.

69 Swann D A, Radin E L, Nazimie C M, Weisser P A, Curran $\mathrm{N}$, Lewinnek $\mathrm{G}$. Role of hyaluronic acid in joint lubrication. Ann Rheum Dis 1974; 33: 318-26.

70 Radin E L, Paul I L. A consolidated concept of joint lubrication. $\mathcal{F}$ Bone foint Surg [Am] 1972; 54: 607-16.

71 Rydell N W. Decreased granulation tissue reaction after instalment of hyaluronic acid. Acta Orthop Scand 1970; 41 307-11.

72 St Onge R, Weiss C, Denglinger J L, Balazs E A. A preliminary assessment of sodium hyaluronate injection into "no mans land" for primary flexor tendon repair. Clin Orthop 1980; 146: 269-75.

73 Weiss C, Suros J M, Michalow A, Denglinger J, Moore M, Tejeiro $W$. The role of sodium-Hylan in reducing postsurgical tendon adhesions. Part 2. Bull Hosp f Dis Orthop Inst 1987; 47: 31-9.

74 Yuzawa K. Experimental study on the healing and restoration of gliding function of the injured digital flexor tendon. Part 9. Use of drugs to prevent adhesion formation of the
injured tendon. Nippon Seikeigeka Gakkai Zasshi 1985; 59: injured tendo.

75 Verdan $\mathrm{C}$. Half a century of flexor tendon surgery. 7 Bone foint Surg $[\mathrm{Am}]$ 1972; 54: 472-91.

76 Quenzer D E, Heck D A, Strickland J W. Pharmacologic modification of flexor tendon healing: quantitative biomechanical evaluation of four agents [Abstract]. Transactions of the American Orthopedic Research Society 35th Annual Meeting 1989; 14: 278.

77 Amiel D, Van de Berg J, Gelberman F R, Ishizue K K, Sisk $A$, Akeson $W$ H. The use of hyaluronic acid in flexor tendon repairs [Abstract]. Transactions of the American Orthopedic Research Society 34th Annual Meeting 1989; 13: 181 .

78 Wiig M E, Amiel D, Harwood F L, Kitabayashi L, Woo S L $Y$, Akeson W H. Anterior cruciate healing: the effect of high molecular weight hyaluronan (hyaluronic acid) high molecular weight hyaluronan (hyaluronic acid) [Abstract]. Transactions of the American Orthop

79 Weiss C, Dennis J, Suros J M, Denlinger J, Badia A, Montane I. Sodium Hylan for the prevention of postlaminectomy scar formation [Abstract]. Transactions of the American Orthopedic Research Society 35th Annual Meeting 1989; 14: 44

80 Balazs A, Denlinger J L. Clinical uses of hyaluronan. The biology of hyaluronan. Chichester: Wiley, 1989: 265-85. (Ciba Foundation Symposium, No 143.) 